\title{
PEMBELAJARAN JIGSAW KONSEP TATA SURYA MELALUI PENDEKATAN IPA REAL LEARNING GUNA MENINGKATKAN HOTS SISWA
}

\author{
Susiana \\ Susianabk116@gmail.com
}

SMP Negeri 3 Kepahiang, Provinsi Bengkulu, Indonesia

Received: 29 Mei $2020 \quad$ Revised: 2 Juni $2020 \quad$ Accepted: 10 Juni 2020

\begin{abstract}
This study aims to determine the improvement of students' High Order Thingking Skills (HOTS) abilities after Jigsaw cooperative learning is applied through the Realistic Learning science approach. This research is a classroom action research with 3 cycles including planning, action implementation, observation and reflection. Data collection techniques in this study were tests, student activity observation sheets, and teacher activity observation sheets. The planning stage in the form of activities (1) making learning tools, (2) making observation sheets and ways of observation, and (3) compiling learning evaluation tools in the form of essay test questions based on cognitive domains C4, C5, and C6. Based on the data obtained by the results of the study are (1) the activity of the first cycle teacher category enough with a score of 47, the second cycle category is good with a score of 54, and the third cycle enough category with a score of 64, (2) the activity of the first cycle category students is enough with a score of 16, the second cycle category is good with a score of 18 , and the third cycle is very good category with a score of 21, and (3) the average score of the students' essay tests in the first cycle is 64.78 , the second cycle is 72.8 , and the third cycle is 82 , 4. It was concluded based on the results of the research that showed that the application of Jigsaw cooperative learning through the Realistic Learning approach could improve the learning activities and learning outcomes of students which illustrated an increase in the High Order Thingking Skills (HOTS) of students in class IX.C of SMP Negeri 3 Kepahiang.
\end{abstract}

\begin{abstract}
Abstrak: Penelitian ini bertujuan untuk mengetahui peningkatan kemampuan High Order Thingking Skills (HOTS) siswa setelah diterapkan pembelajaran kooperatif Jigsaw melalui pendekatan IPA Realistic Learning. Penelitian ini merupakan penelitian tindakan kelas dengan 3 siklus meliputi perencanaan, pelaksanaan tindakan, observasi dan refleksi. Teknik pengumpulan data dalam penelitian ini yaitu tes, lembar observasi aktivitas siswa, dan lembar observasi aktivitas guru. Tahap perencanaan berupa kegiatan (1) membuat perangkat pembelajaran, (2) membuat lembar observasi dan cara observasi, dan (3) menyusun alat evaluasi pembelajaran berupa soal test essay berdasarkan ranah kognitif C4, C5, dan C6. Berdasarkan data diperoleh hasil penelitian yaitu (1) aktivitas guru siklus I kategori cukup dengan skor 47, siklus II kategori baik dengan skor 54, dan siklus III kategori cukup dengan skor 64, (2) aktivitas peserta didik siklus I kategori cukup dengan skor 16, siklus II kategori baik dengan skor 18, dan suklus III kategori sangat baik dengan skor 21, dan (3) Rata - rata nilai tes essay peserta didik pada siklus I adalah 64,78, siklus II adalah 72,8, dan siklus III adalah 82,4. Disimpulkan berdasarkan data hasil penelitian menunjukkan bahwa penerapan pembelajaran kooperatif tipe Jigsaw melalui pendekatan IPA Realistic Learning dapat meningkatkan aktivitas dan hasil belajar peserta didik yang menggambarkan adanya peningkatan High Order Thingking Skills (HOTS) siswa di kelas IX.C SMP Negeri 3 Kepahiang.
\end{abstract}

Kata kunci: Pembelajaran Kooperatif Jigsaw, IPA Realistic Learning, Higher Order Thingking Skills (HOTS) 


\section{PENDAHULUAN}

Pendidikan merupakan investasi jangka panjang yang bila dikelola dengan baik dapat mencerdaskan kehidupan suatu bangsa. Pendidikan merupakan wadah para siswa mencari ilmu, mengembangkanpotensiyang mereka miliki baik potensi akademis maupun potensi nonakademis. Proses pendidikan tidak dapat dipisahkan dari proses pembangunan itu sendiri. Pembangunan dalam pendidikan diarahkan dan bertujuan mengembangkan sumber daya manusia yang berkualitas (Ariani, T, 2017). Kemajuan suatu bangsa sangat ditentukan oleh kualitas sumber daya manusia yang bergantung pada kualitas pendidikan. Pendidikan yang baik pada dasarnya pendidikan yang menghasilkan seseorang yang tinggi kemampuannya untuk belajar (learning to learn), untuk memecahkan masalah (learning to solveproblem), dan untuk hidup (learning to be) (Lovisia, E, 2019).

Dalam proses pembelajaran, strategi pembelajaran memegang peran penting untuk mencapai tujuan pembelajaran. Guru berkewajiban merencanakan strategi pembelajaran yang memberikan kesempatan kepada siswa untuk mengembangkan potensi yang ada pada dirinya melalui kegiatan belajar mengajar dikelas. IPA merupakan pengetahuan yang melalui proses berpikir dan bekerja, sehingga pada pembelajaran IPA dibutuhkan bahan ajar dan strategi yang memenuhi kebutuhan tersebut. IPA seharusnya tidak dibelajarkan sebagai produk saja tetapi harus melalui proses berpikir (way of thingking) sehingga keterampilan berpikir siswa terutama berpikir tingkat tinggi siswa dapat berkembang. Pendidikan IPA merupakan salah satu bagian dari pendidikan yang memiliki potensi besar dan peranan strategis dalam menyiapkan SDM yang berkualitas. Kurikulum IPA SMP menekankan pada pemberian pengalaman secara langsung kepada siswa dalam mempelajari peristiwa yang terjadi di lingkungan sekitar, kehidupan sehari-hari dan masyarakat modern yang sarat dengan teknologi. Sehingga diperlukan pembelajaran yang mengarah pada tumbuhnya kreativitas siswa dengan bimbingan guru yang inovatif. Melalui pendidikan IPA, siswa dapat mempelajari pengetahuan ilmiah dan Melalui pendidikan IPA, siswa dapat mempelajari pengetahuan ilmiah dan keterampilan proses yang dapat digunakan dalam kehidupan seharihari (Anggareni, N. W., Ristiati, N. P., \& Widiyanti, N. L. P. M, 2013).

Kurikulum K13 tidak hanya menekankan pada keterampilan berfikir tingkat rendah/ Lower Order Thingking Skill (LOTS), tetapi juga keterampilan berfikir tingkat tinggi/ Higer Order Thingking Skill (HOTS). HOTS merupakan kemampuan untuk menganalisis, menghubungkan dan mengevaluasi semua aspek situasi dan permasalahan yang didapatkan, termasuk didalamnya mengumpulkan, mengorganisasikan, mengingat, dan menganalisis 
informasi. HOTS termasuk dalam kemampuan membaca dengan pemahaman serta dapat mengidentifikasi materi yang dibutuhkan dan yang tidak dibutuhkan. Kemampuan menarik kesimpulan yang tepat dari data yang telah diberikan dan mampu menentukan ketidak konsistenan dan pertentangan dalam sebuah data ini juga termasuk dalam kemampuan berpikir tingkat tinggi. Hasil belajar kognitif pada peserta didik diukur berdasarkan taksonomi Bloom revisi yang mencakup analisis (C4), evaluasi (C5) dan menciptakan atau kreativitas (C6) (Komariah, N., Mujasam, M., Yusuf, I., \& Widyaningsih, S. W, 2019).

Tujuan pembelajaran dapat tercapai jika pendekatan dan metode pembelajaran yang digunakan guru tepat. Guru harus mempunyai strategi agar pembelajaran menjadi menarik dan siswa dapat belajar secara efektif. Oleh karena itu, pemilihan pendekatan dan metode pembelajaran yang tepat sangat penting, karena tidak semua pendekatan dan metode dapat digunakan pada setiap materi (Azizah, D, 2017). Pada penelitian ini, guru mencoba (1) mengaplikasikan metode pembelajaran Kooperatif tipe Jigsaw. Metode Jigsaw memiliki ciriciri dapat membangkitkann aktivitas belajar siswa, memunculkan sikap saling membantu dan bekerjasama antar anggota kelompok dalam menguasai materi pelajaran, (2) menggunakan pendekatan IPA Realistic Learning, siswa akan berkreasi dalam membuat suatu produk model tata surya berdasarkan langkah - langkah kerja mencapai hasil belajar yang maksimal sehingga dapat meningkatkan Higher Order Thingking Skills Siswa. Pembelajaran kooperatif Jigsaw adalah pembelajaran kooperatif dengan membentuk siswa menjadi kelompok asal dan kelompok ahli, setiap kelompok terdiri atas lima orang siswa yang disesuaikan dengan bagian subbab yang tersedia. Di kelompok asal siswa diberi kategori A, B, C, D, dan E dan siswa dengan bagian yang sama akan berkumpul di kelompok tim ahli. Realistic Learning pada proses pembelajaran diharapkan akan mempermudah siswa dalam memahami konsep dan mengingat data - data secara kuantitas yang terdapat dalam materi tata suryadan dapat menghasilkan produk berupa model susunan planet - planet dalam sistem tata surya dengan ukuran yang berdasarkan skala perbandingan diameter planet berdasarkan data real.

Menurut Sugiman (2011) tipe realistic yang mempunyai ciri pendekatan bottom up dimana siswa mengembangkan model sendiri dan kemudian model tersebut dijadikan dasar untuk mengembangkan matematika formalnya. Pada dasarnya banyakfaktor yang memperngaruhi hasil pembelajaran, diantaranya adalah faktor dari dalam diri siswa itu sendiri yang ditunjukkan dengan aktivitas belajar siswa dikelas.Aktivitas belajar adalah seluruh aktivitas siswa dalam proses belajar, mulai dari kegiatan fisik sampai kegiatan psikis. 
Kegiatan fisik berupa keterampilan-keterampilan dasar sedangkan kegiatan psikis berupa keterampilan terintegrasi. Indikator untuk mengukur kemampuan berpikir tingkat tinggi menurut Krathwohl meliputi analisis, mengevaluasi, dan mengkreasi (Krathwohl, 2002).

Adapun Keterampilan berpikir yang perlu dikembangkan oleh peserta didik dibagi menjadi dua macam yaitu keterampilan berpikir tingkat tinggi (higher order thinking) dan keterampilan berpikir tingkat rendah (lower order thinking).Indikator untuk mengukur kemampuan berpikir tingkat tinggi menurut Krathwohl meliputi analisis, mengevaluasi, dan mengkreasi (Krathwohl, 2002). High Order Thingking Skills (HOTS) peserta didik merupakan satu bentuk dari hasil belajar. Hasil belajar itu sendiri adalah berupa kapabilitas, setelah belajar orang memiliki keterampilan, pengetahuan, sikap, dan nilai. Timbulnya kapabilitas tersebut adalah dari stimulus yang berasal dari lingkungan, dan proses kognitif yang dilakukan oleh pembelajar. Dengan demikian, belajar adalah seperangkat proses kognitif yang mengubah sifat stimulasi lingkungan, melewati pengolahan informasi, menjadi kapabilitas baru. (Dimyati dan Mudjiono, 2006). Menurut Gagne, hasil belajar adalah terbentuknya konsep, yaitu kategori yang kita berikan pada stimulus yang ada di lingkungan, yang menyediakan skema yang terorganisasi untuk mengasimilasi stimulus-stimulus baru dan menentukan hubungan di dalam dan di antara kategori-kategori (Sudjana, 2002).

Berdasarkan hasil pra penelitian, diketahui bahwa terdapat beberapa permasalah yang dialami oleh siswa kelas IX SMP Negeri 3 Kepahiang diantaranya (1) pembelajaran yang digunakan masih menggunakan metode tanya jawab dan ceramah, sehingga pembelajaran berpusat pada guru, (2) rendahnya semangat dan minat belajar siswa untuk belajar IPA, (3) rendahnya kemampuan siswa dalam menganalisis dan menyelesaikan soal yg berkategori High Order Thingking Skills (HOTS). Pembelajaran akan bermakna jika siswa diajak berpikir tingkat tinggi. Keberhasilan penguasaan suatu konsep akan didapatkan ketika siswa sudah mampu berpikir tingkat tinggi, dimana siswa tidak hanya dapat mengingat dan memahami suatu konsep, namun siswa dapat menganalisis serta mensintesis, mengevaluasi, dan mengkreasikan suatu konsep dengan baik, konsep yang telah dipahami tersebut dapat melekat dalam ingatan siswa dalam waktu yang lama, sehingga penting sekali bagi siswa untuk memiliki keterampilan berpikir tingkat tinggi atau HOTS (Ariani, T, 2017). Dari permasalahan tersebut penggunaan Pembelajaran Kooperatif tipe Jigsaw melalui pendekatan IPA Real Learning dianggap dapat menjadi solusi utama agar hasil belajar siswa meningkat.

Berdasarkan latar belakang, maka rumusan masalah penelitian adalah "Apakah Pembelajaran Kooperatif tipe Jigsaw melalui pendekatan IPA Real Learning dapat Puplished at https://ojs.stkippgri-lubuklinggau.ac.id/index.php/SJPIF 
meningkatkan Higher Order Thingking Skills Siswa pada materi Tata Surya di kelas IX.C SMP Negeri 3 Kepahiang?”. Penelitian ini bertujuan untuk mengetahui peningkatan Higher Order Thingking Skills Siswa pada materi tata surya dengan pembelajaran kooperatif tipe Jigsaw melalui pendekatan IPA Real Learning di kelas IX.C SMP Negeri 3 Kepahiang.

Berdasarkan uraian, maka hasil belajar yang dimaksud pada penelitian ini adalah sesuatu yang dicapai atau diperoleh siswa karena adanya usaha atau pemikiran yang terdiri atas nilai Pengetahuan (kognitif), sikap (afektif), dan perilaku (psikomotorik) yang mencakup pada peningkatan High Order Thingking Skills (HOTS) siswa. Aspek pengetahuan diperoleh secara tertulis berbentuk penilaian hariansedangkan aspek sikap (afektif) dan perilaku (psikomotorik) diperoleh melalui lembar observasi aktivitas siswa.

\section{METODE PENELITIAN}

Metode yang digunakan oleh peneliti dalam penelitian ini adalah penelitian tindakan kelas (clasroom action research). Pada penelitian tindakan kelas ini pembelajaran menggunakan pembelajaran kooperatif tipe Jigsaw dengan tujuan meningkatkan High Order Thingking Skills Siswa yang berdasarkan hasil belajar siswa akan dilakukan di SMP Negeri 3 Kepahiang kelas IX. C pada bulan Januari - Maret 2019. Dalam penelitian ini yang menjadi subjek penelitian adalah 25 orang siswa kelas IX. C dengan jumlah siswa perempuan 12 orang siswa dan laki - laki 13 orang siswa. Penelitian dilakukan dalam 3 siklus meliputi kegiatn perencanaan, pelaksanaan tindakan, observasi dan refleksi.Tahap perencanaan berupakegiatan : (1) Membuat Perangkat Pembelajaran, (2) Membuat Lembar Observasi dan cara observasi, (3) Menyusun alat evaluasi pembelajaran.

Jenis Data dan Cara Pengumpulannya adalah : (1) Jenis Data ini adalah kualitatif dan kuantitatif. (2) Cara Pengumpulan Data, yaitu 1). Data Kualitatif diperoleh dari observasi aktivitas guru dan siswa. Observasi aktivitas siswa dan guru dilakukan oleh observator dalam hal ini teman sejawat. Sedangkan data kuantitatif diperoleh melalui hasil Penilaian harian siswa.

Tabel 1. Interval Persentase skor Aktivitas siswa

\begin{tabular}{|l|c|c|c|}
\hline No & Interval Persentase & Skor & Kategori \\
\hline 1. & $<50 \%$ & 1 & Kurang \\
\hline 2. & $50 \%-75 \%$ & 2 & Cukup \\
\hline 3. & $76 \%-90 \%$ & 3 & Baik \\
\hline 4 & $>90 \%$ & 4 & Sangat baik \\
\hline
\end{tabular}

Selanjutnya, berdasarkan data hasil observasi yang diperoleh maka data akan diolah dengan menggunakan persamaan berikut ini : 
1. Rata - rata Skor data kualitatif

$$
\text { Rata }- \text { rata skor }=\frac{\text { Jumlah Skor }}{\text { Jumlah Observer }}(1)
$$

2. Kisaran Nilai untuk tiap aktivitas

$$
\text { Kisaran Nilai untuk Tiap aktivitas }=\frac{\text { selisih skor }}{\text { Jumlah Kriteria tiap penilaian }}(2)
$$

( Sudjana, $2006: 112$ )

Data hasil belajar dianalisis kuantitatif. Hasil belajar siswa merupakan data kuantitatif yang menunjukkan keberhasilan PTK. Hasil belajar siswa dikatakan memenuhi indikator keberhasilan jika(a)Nilai rata-rata kelas lebih dari atau sama dengan 70 (tuntas KKM) dan (b)Persentase tuntas belajar klasikal sekurang-kurangnya 75\% (minimal 75\% siswa yang memperoleh skor lebih dari atau sama dengan 70).

\section{HASIL PENELITIAN DAN PEMBAHASAN \\ 1. Hasil Penelitian}

\begin{tabular}{|c|c|c|c|c|c|c|c|}
\hline \multirow[t]{2}{*}{ No } & \multirow[t]{2}{*}{ KEGIATAN } & \multicolumn{2}{|c|}{$\begin{array}{l}\text { SKOR } \\
\text { siklus I }\end{array}$} & \multicolumn{2}{|c|}{$\begin{array}{l}\text { SKOR } \\
\text { Siklus II }\end{array}$} & \multicolumn{2}{|c|}{$\begin{array}{l}\text { SKOR } \\
\text { Siklus III }\end{array}$} \\
\hline & & $\mathrm{P} 1$ & $\mathrm{P} 1$ & P1 & $\mathrm{P} 2$ & $\mathrm{P} 2$ & $\mathrm{P} 2$ \\
\hline 1 & Motivasi dan Apersepsi & 3 & 3 & 3 & 3 & 4 & 4 \\
\hline 2 & Penjelasan Materi & 3 & 3 & 3 & 3 & 3 & 3 \\
\hline 3 & $\begin{array}{l}\text { Penjelasan model dan metode } \\
\text { pembelajaran yang digunakan }\end{array}$ & 3 & 3 & 3 & 3 & 3 & 3 \\
\hline 4 & Teknik pembagian kelompok & 2 & 2 & 2 & 2 & 4 & 4 \\
\hline 5 & Penguasaan kelas & 3 & 3 & 3 & 3 & 3 & 3 \\
\hline 6 & Penggunaan media & 2 & 2 & 3 & 3 & 4 & 4 \\
\hline 7 & Suara & 4 & 4 & 4 & 4 & 4 & 4 \\
\hline 8 & Pengelolaan kegiatan diskusi & 2 & 2 & 3 & 3 & 3 & 3 \\
\hline 9 & Bimbingan kepada kelompok & 3 & 3 & 3 & 3 & 4 & 4 \\
\hline 10 & Pengelolaan kegiatan diskusi & 2 & 2 & 3 & 3 & 3 & 3 \\
\hline 11 & Pemberian pertanyaan atau kuis & 2 & 2 & 3 & 3 & 4 & 4 \\
\hline 12 & Kemampuan melakukan evaluasi & 2 & 2 & 3 & 3 & 4 & 4 \\
\hline 13 & $\begin{array}{l}\text { Memberikan penghargaan individu dan } \\
\text { kelompok }\end{array}$ & 2 & 2 & 3 & 3 & 4 & 4 \\
\hline 14 & Menentukan nilai individu dan kelompok & 2 & 2 & 3 & 3 & 3 & 3 \\
\hline 15 & $\begin{array}{l}\text { Mengarahkan siswa menyimpulkan materi } \\
\text { pembelajaran }\end{array}$ & 3 & 3 & 3 & 3 & 3 & 3 \\
\hline 16 & $\begin{array}{l}\text { Memberi penguatan kepada siswa tentang } \\
\text { materi pembelajaran yang telah dipelajari }\end{array}$ & 3 & 3 & 3 & 3 & 4 & 4 \\
\hline 17 & Melakukan refleksi & 3 & 3 & 3 & 3 & 3 & 3 \\
\hline 18 & Menutup pelajaran & 3 & 3 & 3 & 3 & 4 & 4 \\
\hline & JUMLAH SKOR & 47 & 47 & 54 & 54 & 64 & 64 \\
\hline & RATA - RATA & \multirow{2}{*}{\multicolumn{2}{|c|}{$\begin{array}{c}47 \\
650 \%\end{array}$}} & \multicolumn{2}{|c|}{64} & \multicolumn{2}{|c|}{47} \\
\hline & PERSENTASE & & & \multicolumn{2}{|c|}{$75 \%$} & \multicolumn{2}{|c|}{$89 \%$} \\
\hline
\end{tabular}

Tabel 4.2. Hasil observasi aktivitas guru siklus I, II, dan III

Puplished at https://ojs.stkippgri-lubuklinggau.ac.id/index.php/SJPIF 


\begin{tabular}{lcc} 
KATEGORI CUKUP & BAIK & $\begin{array}{c}\text { SANGAT } \\
\text { BAIK }\end{array}$ \\
\hline
\end{tabular}

Tabel 4.3 Hasil observasi aktivitas Peserta didiksiklus I, II, dan III

\begin{tabular}{|c|c|c|c|c|c|c|c|}
\hline \multirow{2}{*}{$\begin{array}{c}\text { No } \\
\text {. }\end{array}$} & \multirow[t]{2}{*}{ Langkah Pembelajaran } & \multicolumn{2}{|c|}{ Siklus I } & \multicolumn{2}{|c|}{ Siklus II } & \multicolumn{2}{|c|}{ Siklus III } \\
\hline & & $\mathrm{P} 1$ & $\mathrm{P} 2$ & $\mathrm{P} 1$ & $\mathrm{P} 2$ & $\mathrm{P} 1$ & $\mathrm{P} 2$ \\
\hline 1 & Pengelompokkan & 3 & 3 & 4 & 3 & 4 & 4 \\
\hline 2 & Pemberian Tugas & 2 & 3 & 3 & 3 & 3 & 3 \\
\hline 3 & 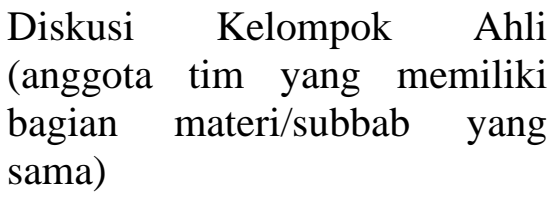 & 3 & 2 & 3 & 3 & 3 & 3 \\
\hline 4 & Kembali ke kelompok asal & 2 & 2 & 3 & 3 & 4 & 4 \\
\hline 5 & Presentasi Hasil Diskusi & 3 & 3 & 2 & 2 & 3 & 3 \\
\hline 6 & Evaluasi & 3 & 3 & 3 & 3 & 4 & 4 \\
\hline & Jumlah & 16 & 16 & 18 & 18 & 21 & 21 \\
\hline & Rata-rata & & & & & & \\
\hline & Persentase Skor & & & & & & \\
\hline & Kategori Skor & $\mathrm{CL}$ & & & & SAN & BAIK \\
\hline
\end{tabular}

Tabel 4.4. Hasil Belajar Peserta didik menggunakan Test Essay Siklus I, II, dan III

\begin{tabular}{llccc}
\hline No. & Deskripsi nilai hasil belajar & Nilai & Nilai & Nilai \\
& & Siklus I & Siklus II & Siklus III \\
1. & Nilai terendah & 45 & 66,6 & 75 \\
2. & Nilai tertinggi & 70 & 85 & 180 \\
3. & Rata-rata & 64,78 & 72,8 & 82,4 \\
4. & Daya serap & $64,78 \%$ & $72,8 \%$ & $82,4 \%$ \\
5. & Ketuntasan belajar & $65 \%$ & $73 \%$ & $82 \%$ \\
\hline
\end{tabular}

\section{PEMBAHASAN}

Pembelajaran Jigsaw melalui pendekatan Realistic Learning pada pelajaran IPA konsep Tata Surya dimaksudkan sebagai pendekatan pembelajaran yang menggunakan data real. Siswa menggunakan data real untuk mempermudah siswa dalam memahami konsep dan mengingat data - data secara kuantitas yang terdapat dalam materi tata surya. Siswa diminta membuat model Matahari dan planet menggunakan bahan yang mereka pilih sendiri yang berdasarkan rasio diameter planet dan jarak antar planet.

\section{Aktivitas Guru}

Data hasil penelitian pada proses pembelajaran menggunakanmodel pembelajaran Kooperatif Jigsaw melalui pendekatan IPA Realistic Learning agar menjadi lebih bermakna, Puplished at https://ojs.stkippgri-lubuklinggau.ac.id/index.php/SJPIF 
sebagaimana diusulkan oleh Lawson dalam Nurohman (2008), dimulai dari pemberian pertanyaan menantang tentang suatu fenomena, kemudian menugaskan peserta didik untuk melakukan suatu aktivitas, memusatkan pada pengumpulan dan penggunaan bukti, bukan sekedar penyampaian informasi secara langsung dan penekanan pada hafalan.

Peningkatan ini disebabkan oleh perbaikan - perbaikan yang dilakukan guru pada tiap siklus.Grafik 4.1 menunjukkan bahwa aktivitas guru meningkat dari siklus I sampai siklus III dimana ketiga siklus berada pada kategori baik. Peningkatan aktivitas guru ini di tunjukkan pada Grafik 4.1.

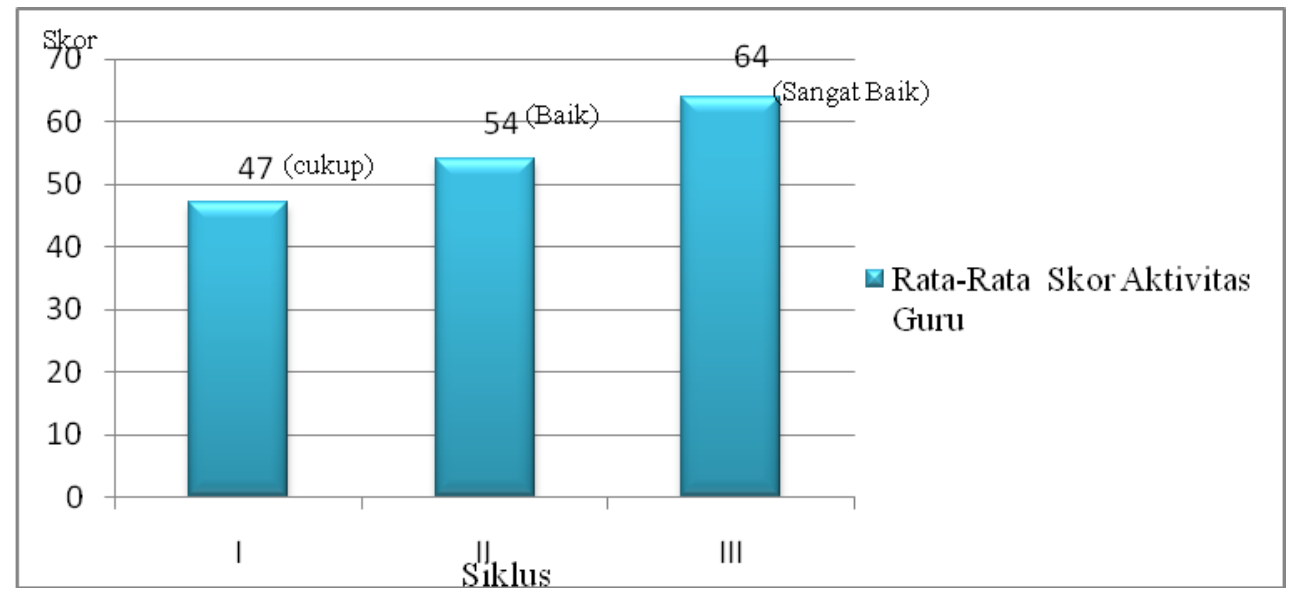

Gambar 4.1. Grafik Perkembangan skor aktivitas guru

Grafik 4.1 rata-rata skor aktivitas guru pada siklus I adalah 47 yang berada pada kategori Cukup. Meskipun demikian, pada saat melaksanakan kegiatan pembelajaran masih terdapat banyak kekurangan pada aktivitas guru. Kemampuan guru dalam membimbing seluruh kelompok dalam pembagian tugas kerja belum maksimal. Guru belum memastikan setiap anggota kelompok mendapatkan tugas. Hal ini terjadi karena guru sudah pindah untuk membimbing kelompok lainnya padahal kelompok yang sedang dibimbing belum selesai membagi tugas kerja pada seluruh anggota kelompoknya. Kemudian kemampuan guru dalam mengkoordinasikan jalannya presentasi masih lemah sehingga suasana proses presentasi tidak kondusif. Hal ini terjadi karena memang guru masih belum berpengalaman dan posisi guru berdiri masih salah yaitu tidak berada di tengah - tengah antara tempat duduk anggota kelompok. Kemampuan guru juga lemah saat proses tanya jawab berlangsung. Guru kurang mampu merangsang keinginan Peserta didik untuk bertanya. Pada tahap evaluasi guru juga belum melakukan pengawasan yang ketat yaitu tidak berkeliling mengawasi hingga tempat duduk Peserta didik yang paling belakang dan belum memiliki strategi yang bagus untuk membuat seluruh Peserta didik mengerjakan soal secara mandiri. 
Jika dilihat dari lembar observasi guru pada siklus satu di item nomor 12 yaitu kemampuan melakukan evaluasi dimana guru menilai sikap peserta didik dalam kerja kelompok, observer 1 memberikan penilaian 1 sedangkan observer 2 memberikan skor penilaian 2 setelah pembelajaran selesai guru berdiskusi kepada observer bahwa menurut observer 1 guru masih kurang memberikan penilaian sikap Peserta didik dalam kerja kelompok karena tidak terlihat guru membawa lembar penilaian pada saat kerja kelompok berlangsung, namun observer 2 melihat lembar penilaian diisi pada saat guru sedang duduk dimeja guru. Untuk item nomor 11 guru meminta beberapa Peserta didik untuk menjelaskan kembali apa yang telah dipaparkan oleh kelompok yang maju dengan cara memilih acak, pada item ini juga terdapat perbedaan yang mencolok antara observer 1 dan observer 2, dengan masukkan bahwa guru masih belum memberi penegasan agar Peserta didik mendengarkan pemaparan dari kelompok lain sehingga banyak Peserta didik yang kurang bisa menjelaskan kembalii pemaparan hasil diskusi kelompok lain.Kelemahan yang terjadi pada siklus I diperbaiki pada siklus berikutnya dan hal yang baik tetap dipertahankan.

Siklus II rata-rata skor aktivitas guru mengalami peningkatanmenjadi 54 dan termasuk dalam kategori baik. Guru sudah melakukan perbaikan dalam proses pembelajaran berdasarkan refleksi pada siklus I. Perbaikan yang dilakukan guru pada saat guru melakukan bimbingan terhadap seluruh kelompok untuk melakukan pembagian tugas kerja. Peningkatan kemampuan juga ditunjukkan oleh guru pada tahap presentasi. Guru sudah mampu mengkoordinasikan jalannya presentasi tetapi masih sedikit kurang kondusif. Anggota kelompok sudah berusaha aktif membantu jalannya presentasi hanya saja masih ada 1 atau 2 orang di setiap kelompok yang kurang aktif. Pada tahap implementasi terjadi penurunan kemampuan guru dalam mengawasi Peserta didik dalam proses penyelidikan. Hal ini karena guru tidak mengawasi seluruh Peserta didik saat melakukan penyelidikan. Secara keseluruhan aktivitas guru pada siklus II ini sudah lebih baik dari siklus I. Namun, kemampuan guru masih harus perlu ditingkatkan demi pencapaian proses pembelajaran yang dapat lebih meningkatkan aktivitas dan hasil belajar Peserta didik.

Siklus III rata-rata skor aktivitas belajar Peserta didik meningkat menjadi 64 dan termasuk dalam kategori baik. Secara keseluruhan kemampuan guru dalam menjalankan tahapanmodel pembelajaran Kooperatif Jigsaw melalui pendekatan IPA Realistic Learning telah mengalami peningkatan dari setiap siklus, peningkatan ini dapat terjadi karena meningkatkan item yang masih kurang dan mempertahankan item yang sudah baik sehingga peningkatan aktivitas guru terlihat dengan sangat baik. 


\section{Aktivitas Belajar Peserta didik}

Data hasil observasi aktivitas belajar Peserta didik yang mengikuti proses pembelajaran menggunakanmodel pembelajaran Kooperatif Jigsaw melalui pendekatan IPA Realistic Learning terlihat dari siklus I sampai siklus III aktivitas belajar Peserta didik meningkat. Dimana pada siklus I, siklus II, dansiklus III mengalami peningkatan karena adanya perbaikan - perbaikan yang dilakukan guru dan peserta didik pada tiap siklusnya.Peningkatan aktivitas belajar Peserta didik ini dapat dilihat dari Grafik 4.2.

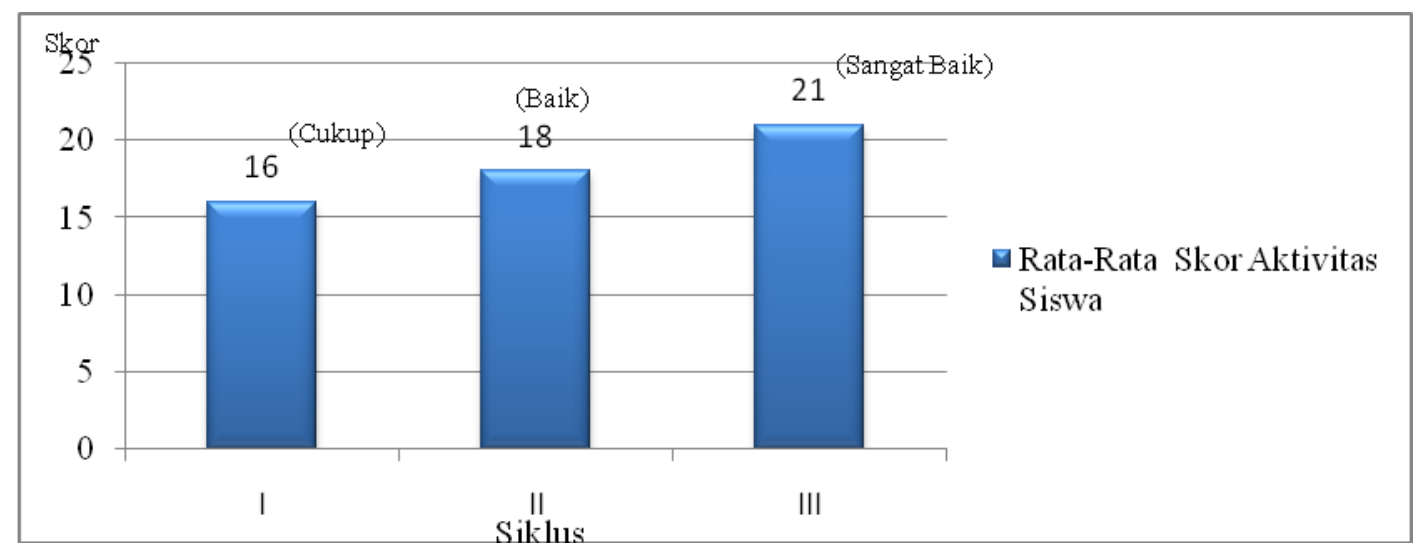

Gambar 4.2 Grafik Perkembangan skor aktivitas belajar Peserta didik

Gambar 4.2rata-rata skor aktivitas belajar Peserta didik pada siklus I adalah 16 kategori Cukup. Kategori ini memperlihatkan bahwa aktivitas belajar Peserta didik pada siklus I ini belum terlihat maksimal namun terdapat beberapa kekurangan yang dilakukan Peserta didik secara individu ataupun secara berkelompok. Terdapat beberapa item pengamatan aktivitas belajar Peserta didik yang masuk kategori baik, dan item lainnya masuk kategori cukup. Hal ini disebabkan Peserta didik belum sepenuhnya mengikuti instruksi dari guru. Tahap pemberian permasalahan awal Peserta didik masih belum fokus seutuhnya kepada proses pembelajaran. Peserta didik masih sulit untuk mencari informasi sebanyak - banyaknya dari hasil demonstrasi perwakilan Peserta didik. Peserta didik juga masih butuh diinstruksi untuk mengingat hal - hal penting yang berkaitan dengan pembelajaran. Proses diskusi berlangsung pada siklus I hanya ada 50\% Peserta didik atau 3 sampai 4 orang Peserta didik dalam anggota kelompok yang ikut berkontribusi dalam menyelesaikan tugas kelompok dan pemaparan hasil diskusi kelompok.

Tahap evaluasi seharusnya seluruh Peserta didik mengerjakan soal tes secara mandiri. Akan tetapi hanya $75 \%$ Peserta didik yang mengerjakan soal tes secara mandiri sedangkan yang lainnya masih melakukan pelanggaran dengan mencontek atau terlambat mengumpulkan hasil jawaban tes.Tempat duduk Peserta didik ketika mengerjakan soal tes pada siklus I memang sudah tersusun dengan rapi namun masih terdapat beberapa Puplished at https://ojs.stkippgri-lubuklinggau.ac.id/index.php/SJPIF 
pelanggaran.Kelemahan - kelemahan aktivitas belajar Peserta didik pada siklus I kemudian di perbaiki pada siklus II dan yang telah baik tetap di pertahankan.

Siklus II rata-rata skor aktivitas belajar Peserta didik meningkat 2 poin menjadi 18 (kategori baik). Peningkatan ini disebabkan oleh beberapa hal di antaranya Peserta didik sudah mulai terbiasa dengan pembelajaran yang diterapkan oleh guru dan guru telah memperbaiki kelemahan yang terjadi pada proses belajar mengajar sebelumnya.

Peningkatan yang belum maksimal juga pada proses tanya jawab. Tidak semua kelompok aktif untuk bertanya.Pada siklus II ini terdapat 3 kelompok yang aktif bertanya.Kemudian pada tahap evaluasi perbaikan telah dilakukan dengan memberikan jarak yang cukup jauh antara Peserta didik ketika mengerjakan soal tes dan berkeliling mengawasi Peserta didik hingga tempat duduk paling belakang.Cara ini telah mampu menekan tingkat kucurangan yang dilakukan Peserta didik, tetapi masih ada Peserta didik yang mencontek dan terlambat mengumpulkan hasil jawaban tes. Meskipun proses pembelajaran pada siklus II sudah baik, tetapi agar tercapai hasil yang lebih baik maka dilakukan perbaikan pada siklus selanjutnya pada aspek - aspek yang masih kurang.

Siklus III rata-rata skor aktivitas belajar Peserta didik meningkat menjadi 21 yang masuk dalam kategorisangat baik. Guru telah memperbaiki kelemahan dan kekurangan yang terjadi pada proses belajar mengajar pada siklus II, sehingga aktivitas Peserta didik dapat meningkat.Peningkatan ini di tunjukkan seluruh item mendapatkan penilaian dalam kategori sangat baik.

Peningkatan juga terlihat pada pembagian tugas kerja diskusi kelompok, selain Peserta didik telah terbiasa melakukan pembagian tugas kerja pada siklus sebelumnya, guru membimbing pembagian tugas kerja dengan cara tidak berpindah membimbing kelompok lain sebelum kelompok tersebut semua anggotanya mendapat tugas kerja. Kemudian pada proses tanya jawab juga terjadi peningkatan, hal ini karena guru memberikan ajakan pada kelompok pendengar untuk aktif bertanya dengan cara memberikan contoh hal - hal yang dapat di tanyakan. Tahap evaluasi juga telah terjadi peningkatan dimana kesadaran Peserta didik untuk mengerjakan soal tes secara mandiri sudah baik dan guru terus mengamati Peserta didik ketika mengerjakan soal tes serta jarak antara Peserta didik yang cukup jauh mampu menekan angka kecurangan yang dilakukan Peserta didik.Uraian di atas, aktivitas belajar Peserta didik dalam mengikuti kegiatan pembelajaran dengan menggunakan model pembelajaran Kooperatif Jigsaw melalui pendekatan IPA Realistic Learning telah mengalami perbaikan dan peningkatan. 


\section{Hasil belajar dengan test}

Hasil belajar Peserta didik setelah proses belajar menggunakan model Kooperatif Jigsaw melalui pendekatan IPA Realistic Learning mengalami peningkatan dibanding dengan pada saat guru masih menggunakan cara konvensional pada proses belajar. Peningkatan hasil belajar Peserta didik terlihat dari nilai rata-rata yang meningkat, yang ditunjukan pada grafik 4.3 .

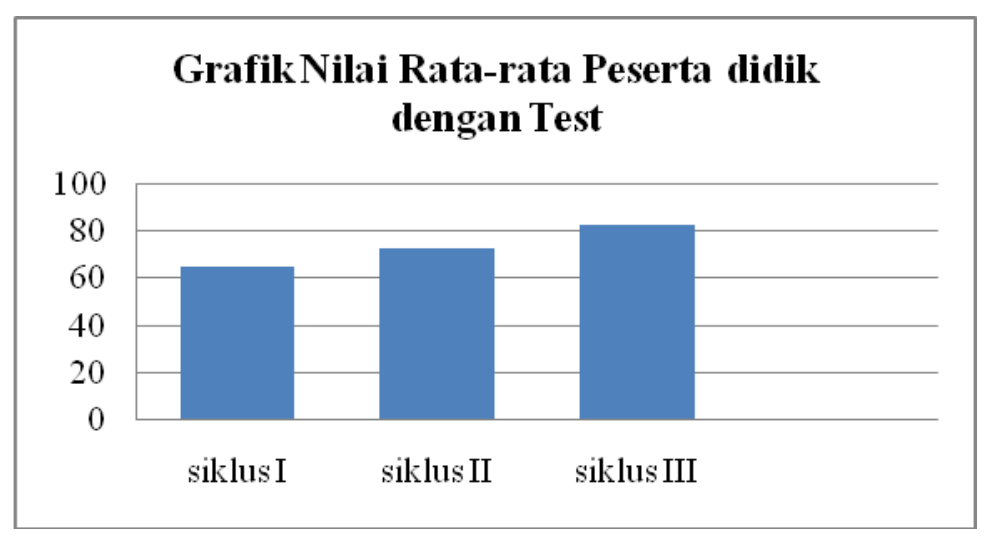

Gambar 4.3. Grafik Peningkatan Hasil Belajar Peserta didik dengan Test

Pada siklus I nilai rata-rata Peserta didik belum cukup tinggi yaitu 64,78. Pada siklus I masih banyak Peserta didik tidak memperhatikan penjelasan guru, Peserta didik tidak antusias terhadap proses belajar di kelas. Peserta didik masih menyontek saat mengisi jawaban lembar test, sehingga hasil belajar pada siklus I belum optimal.

Terlihat pada grafik, di siklus II nilai rata-rata Peserta didik mulai menunjukkan peningkatan yaitu 72,8. Peserta didik sudah mulai mengikuti proses belajar dengan baik, walaupun beberapa Peserta didik masih terlihat tidak serius saat belajar. Walaupun hasil belajar sudah meningkat, siklus III tetap dilakukan untuk melihat apakah model Kooperatif Jigsaw melalui pendekatan IPA Realistic Learning benar-benar dapat diterapkan di kelas IX.C SMP Negeri 3 Kepahiang.

Pada siklus III, semua Peserta didik ikut terlibat dalam proses belajar dengan baik. Peserta didik mengisi lembar jawaban test dengan baik, walaupun masih ada yang menjawab kurang tepat. Peningkatan nilai rata-rata Peserta didik dapat dilihat pada gambar 4.3 yaitu 82,4 .

Peningkatan nilai rata-rata Peserta didik ini menunjukkan bahwa model Pembelajaran Kooperatif Jigsaw melalui pendekatan IPA Realistic Learning berhasil diterapkan di kelas IX.C SMP Negeri 3 Kepahiang, walaupun masih ada kekurangan yang harus diperbaiki pada proses belajar selanjutnya. 


\section{SIMPULAN}

Berdasarkan hasil penelitian dan pembahasan dapat ditarik kesimpulan bahwa:

1. Penerapan model pembelajaran Kooperatif Jigsaw melalui pendekatan IPA Realistic Learning dapat meningkatkan aktivitas belajar IPA Peserta didik kelas IX.C SMP N 3 Kepahiang, pada siklus I rata - rata skor sebesar dengan skor 16 (67\%) kritera cukup, pada siklus ke II rata - rata skor 18 (75\%) dengan kriteria baik, dan pada siklus III rata rata skor sebesar $21(87,5 \%)$ kriteria sangat baik. Aktivitas belajar Peserta didik meningkat terutama pada saat melakukan tahap prsentasi hasil kerja dan diskusi.

2. Penerapan model pembelajaran Kooperatif Jigsaw melalui pendekatan IPA Realistic Learning dapat meningkatkan hasil belajarIPA Peserta didik kelas IX.C SMP N 3 Kepahiang. Pada siklus I nilai rata - rata diperoleh 64,78, disiklus kedua nilai rata- rata 72,8 dan disiklus ketiga diperoleh nilai rata - rata 82,4 dan ini menunjukkan adanya peningkatan High Order Thingking Skills (HOTS) Siswa.

\section{DAFTAR PUSTAKA}

Anderson dan Krathwohl. 2002. Revisi Taksonomi Bloom. Jakarta: Rineka Cipta.

Anggareni, N. W., Ristiati, N. P., \& Widiyanti, N. L. P. M. (2013). Implementasi strategi pembelajaran inkuiri terhadap kemampuan berpikir kritis dan pemahaman konsep IPA siswa SMP. Jurnal Pendidikan dan Pembelajaran IPA Indonesia, 3(1).

Ariani, T. (2017). Penerapan Strategi Pembelajaran Ekspositori Untuk Meningkatkan Hasil Belajar Fisika. Jurnal Inovasi dan Pembelajaran Fisika, 4(1), 19-26.

Ariani, T. (2017). Pembelajaran Kooperatif Tipe Team Assisted Individualization (TAI): Dampak Terhadap Hasil Belajar Fisika Siswa. Jurnal Ilmiah Pendidikan Fisika AlBiRuNi, 6(2), 169-177.

Azizah, D. (2017). Eksperimentasi Pembelajaran Realistik ditinjau dari Aktivitas Belajar Siswa pada Materi Segiempat. Delta: Jurnal Ilmiah Pendidikan Matematika, 1(1), 5769.

Dimyati dan Mudjiono. 2006. Belajar dan Pembelajaran. Jakarta: PT Rineke Cipta

Hamalik, Oemar. (2006). Proses Belajar dan Pembelajaran. Jakarta : PT. Rineka Cipta

Isjoni. (2007). Cooperatif Learning. Jakarta. Pustaka Pelajar.

Komariah, N., Mujasam, M., Yusuf, I., \& Widyaningsih, S. W. (2019). Pengaruh Penerapan Model PBL Berbantuan Media Google Classroom terhadap HOTS, Motivasi dan Minat Peserta Didik. SILAMPARI JURNAL PENDIDIKAN ILMU FISIKA, 1(2), 102-113.

Lovisia, E. (2019). Penerapan Model Pembelajaran Kooperatif Tipe Student teams achievement division (STAD) pada pembelajaran fisika siswa kelas X SMA Negeri 7 Lubuklinggau. Silampari Jurnal Pendidikan Ilmu Fisika, 1(1), 1-12.

Sadirman. (2001). Interaksi dan Motivasi Belajar mengajar. Jakarta : PT Raja Grafindo Persada 
Sudjana. (2004). Metode Statistika. Bandung : Tarsito

Sudjana, Nana. (2002). Bandung : PT. Remaja Rosdakarya.

Komalasari, Kokom. (2013). Pembelajaran Kontekstual. Bandung. Refika Aditama.

Cahya, dkk. (2012). Tata Surya. Jakarta. Erlangga 